\title{
Problems and Possible Solutions of Communication Education in the Turkish Education System: Department Name Problems
}

\author{
Mustafa Özgür Seçim \\ Adnan Menderes University, Faculty of Communication \\ ozgur.secim@adu.edu.tr
}

\begin{abstract}
Communication education in the Turkish higher education system has been improving every year. In 2017 more then 35 faculties named as communication are accepting students and every year almost 700 students are graduating from these faculties. In this study, it is tried to be found what are the major problems of these faculties in terms of they have so many different department names and also it is tried to suggest some solutions for these problems.
\end{abstract}

\section{Introduction}

There was really "Communication First" as stated in the title of the book of Alaeddin Asna, a famous communication academician whom we lost in 2015. The democratization process that accelerated with the transition to a multi-party political life in Turkey during the 1950s brought about the requirement to reach more people, and in this regard, it became essential to increase both the access to mass media and the number of experts who could use it. While the most important mass media in that period appeared to be newspapers and radio, in today's world, the broad spectrum of means of communication from social media to cell phones, from the Internet to digital cameras form our lives. Using these tools effectively and transmitting the desired message to the target audience are very important both for the state mechanism and private sector. This is because the fact that the target audience understands the desired message in a different way or it does not reach the target audience at all causes a big confusion and leads to a 'communication accident'. During this process, the qualified labour force is the only way to eliminate this problem. For the very reason, a substantial increase occurs in the number of communication faculties in parallel with an increase in the number of universities in Turkey. For universities, communication faculties are evaluated not only as units transmitting university news to more people by publishing student newspapers or supporting university advertisement with the radio or television channels they have but also as units to have a voice in the construction of future thanks to qualified students they train.

While the process conduces to the fact that more students receive communication education by preferring these faculties each year, it also ensures that students graduate and participate in the media sector by completing this training. While various studies were carried out in the past regarding the dimension of the subject related to employment and the problems encountered (Uzun,2007, Tokgöz,2003, Arslan,2015, Örücü and Şimşek,2011), another problem that is as important as the subject of employment has been revealed in time. This problem is the name problem of the departments taught at universities especially with the increase in the number of foundation universities. A discussion will be developed in this study over the existing department names of the Faculties of Communication in the 2016 "Student Selection and Placement System Higher Education Programs and Quotas Guide". A general discussion will be made upon questions such as "Which departments exist in the present faculties?", 
"What is the most frequently used department name?", "What are possible problems that different department names can lead to?"

\section{Overall Situation of the Faculties of Communication in Turkey:}

The "communication" education that first began to be given at Ankara University under the name of Press-Publication Higher Education School in 1965 expanded in future years both with the needs of the sector and technological developments. Nowadays, the number of the faculties of communication that can be selected by the OSYM (Assessment Selection and Placement Centre) has reached fifty. While twenty-six of these fifty universities are foundation universities, twenty-four state universities have communication faculties. In other words, foundation universities that have increased rapidly in number in the recent period attract as much attention to communication education as state universities, and they have even left behind state universities, although low in number.

Table 1: The state and foundation rate of the universities where communication education is given in Turkey, TRNC and Kirghizstan.

\section{Universities that provide communication education}

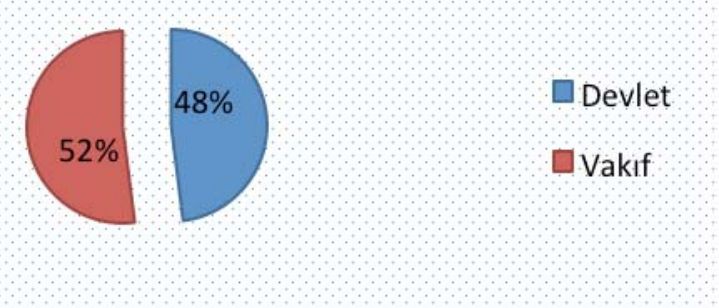

Devlet: State

Vakıf: Foundation

In an assessment to be carried out upon the present department names of these fifty universities that provide communication education, the department names incorporated by the faculties were found to be as follows:

Abant Izzet Baysal University: Journalism, Visual Communication Design, Radio, Television and Cinema, Public Relations and Publicity

Adnan Menderes University: Public Relations and Advertising, Radio-TV and Cinema, Journalism, Visual Communication Design

Akdeniz University: Journalism, Public Relations and Publicity, Radio-Television and Cinema

Anadolu University: Press and publication, Public Relations and Advertising, Communication Design and Management, Cinema and Television.

Ankara University: Journalism, Public Relations and Publicity, Radio-Television and Cinema

Atatürk University: Journalism, Public Relations and Publicity, Radio, Television and Cinema

Bahçeşehir University: Digital Game Design, Public Relations, Communication Design, Advertising, Cinema and Television, New Media, Photography and Video.

Başkent University: Public Relations and Publicity, Communication Design, RadioTelevision and Cinema

Beykent University: Visual Communication, Public Relations and Advertising, Media and Communication, Television Journalism and Programming, New Media 
Cumhuriyet University: Journalism, Public Relations and Publicity, Radio-TV and Cinema

Çukurova University: Communication Sciences, Radio-TV and Cinema, Journalism, Advertising and Public Relations

Dicle University: Public Relations and Publicity

Ege University: Journalism, Public Relations and Publicity, Radio, TV and Cinema, Advertising, Visual communication design

Erciyes University: Journalism, Public Relations and Publicity, Radio, TV and Cinema

Fırat University: Journalism, Public Relations and Publicity, Radio-TV and Cinema

Galatasaray University: No department exists.

Gaziantep University: Journalism, Public Relations and Publicity, Radio-TV and Cinema,

Giresun University: Journalism, Public Relations and Publicity, Radio-TV and Cinema

Gümüşhane University: Journalism, Public Relations and Publicity, Radio TV and Cinema.

Inönü University: Journalism, Public Relations and Publicity, Radio-TV and Cinema.

Arel University: Journalism, Visual Communication Design, Public Relations and Advertising, Media and Communication Systems, Radio-TV and Cinema

Aydın University: Journalism, Visual Communication Design, Public Relations and Publicity, Radio-TV and Cinema, Advertising, Television Journalism and Programming.

Bilgi University: Visual Communication Design, Public Relations, Communication Design and Management, Media and Communication Systems, Advertising, Art and Culture Management, Cinema and Television, Television Journalism and Programming, Stage and Performing Arts Management.

Istanbul University: Journalism, Public Relations and Publicity, Radio-TV and Cinema.

European University of Lefke: Visual Communication Design, Public Relations and Advertising, Radio-TV and Cinema, New media and journalism.

Izmir Economy University: Public Relations and Advertising, Media and Communication, Cinema and Digital Media.

Kadir Has University: Visual Communication Design, Public Relations and Publicity, Radio-TV and Cinema, Advertising, New Media.

Karadeniz Technical University: Journalism, Public Relations and Advertising, RadioTV and Cinema

Kastamonu University: Journalism, Public Relations and Advertising, Radio-TV and Cinema.

Medipol University: Journalism, Public Relations and Advertising, media and visual arts, new media and communication systems.

Istanbul Şehir University: Public Relations, Cinema and Television.

Istanbul Ticaret University: Visual Communication Design, Public Relations and Advertising, Media and Communication Systems

Maltepe University: Journalism, Visual Communication Design, Public Relations and Publicity, Radio-TV and Cinema.

19 Mayıs University: Journalism, Public Relations and Publicity, Radio-TV and Cinema.

Pamukkale University: Public Relations and Publicity, Journalism, Radio-TV and Cinema, New Media.

Sakarya University: Journalism, Public Relations and Advertising, Communication Design and Media

Selçuk University: Journalism, Public Relations and Publicity, Radio-TV and Cinema, Advertising.

Süleyman Demirel University: Public Relations and Publicity, Radio-TV and Cinema. Uşak University: Journalism, Public Relations and Advertising, Radio-TV and Cinema, New Media.

Üsküdar University: Visual Communication Design, Public Relations, Media and Communication Systems, Radio-TV and Cinema, Advertising Design and Communication, New Media and Journalism. 
Girne American University: Press and Information, Public Relations, Radio Television and Cinema

Cyprus International University: Journalism, Radio and Television, Advertising and Public Relations.

Near East University: Journalism, Visual Communication Design, Public Relations and Publicity, Radio TV and Cinema.

Hoca Ahmed Yesevi International Turkish-Kazakh University: Journalism.

Kyrgyzstan-Turkey Manas University: Journalism, Public Relations and Advertising, Radio-TV and Cinema

Eastern Mediterranean University: Animation and Game Design, Journalism, Visual Arts and Visual Communication Design, Public Relations and Advertising, Radio-TV and Cinema.

Yaşar University: Visual Communication Design, Public Relations and Advertising, Radio-TV and Cinema, New Media.

Yeditepe University: Journalism, Visual Communication Design, Public Relations and Publicity, Radio TV and Cinema, Advertising Design and Communication.

Yeni Yüzyıl University: Visual Communication Design, Public Relations and Advertising, Radio TV and Cinema, New Media and Journalism.

International Balkan University: Public Relations, New Media and Communication.

The most and least used department names were found to be as follows in the examination to be performed on department names:

Table 2: The ratio of different department names used at the faculties of communication

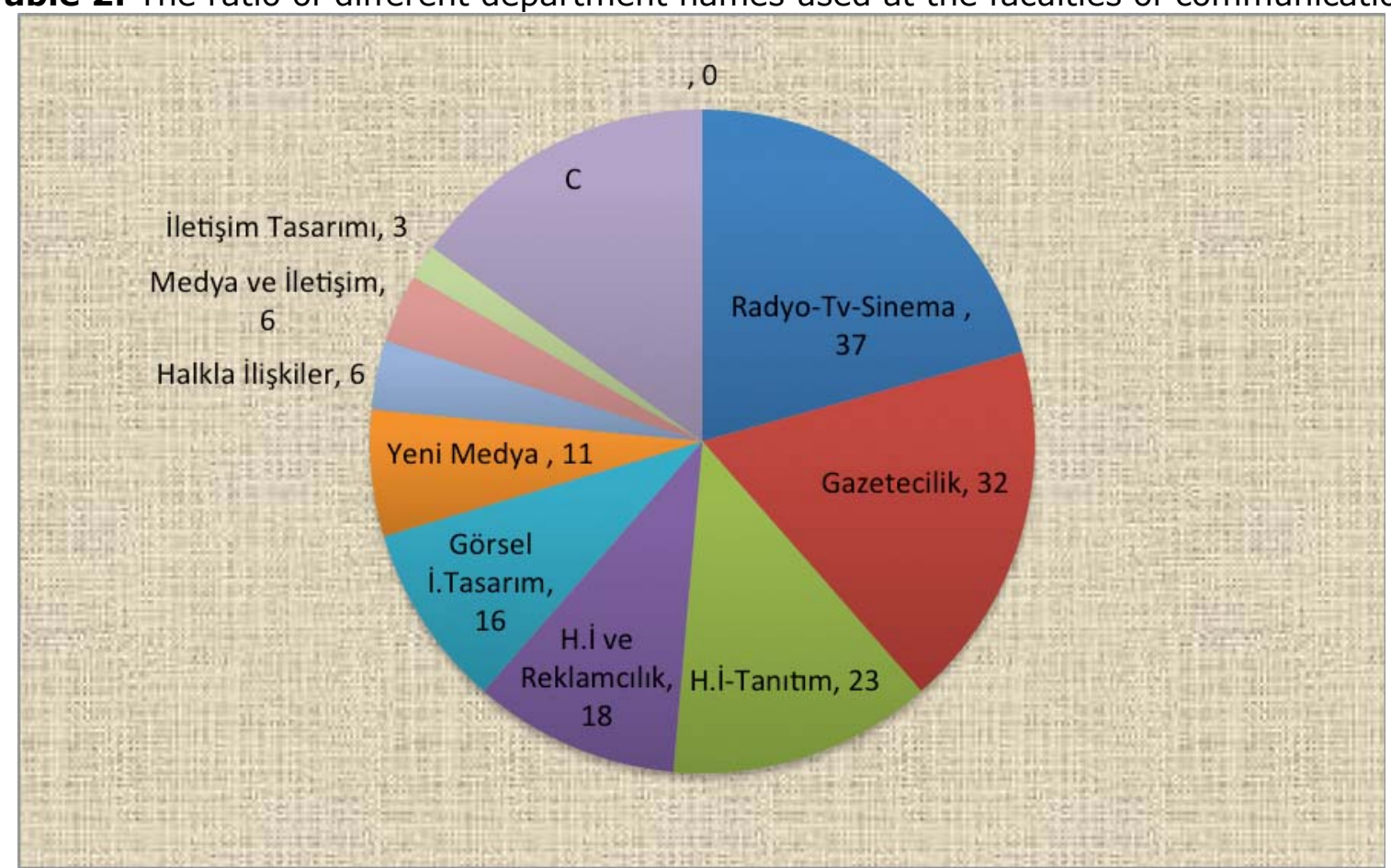

İletişim Tasarımı: Communication Design

Medya ve İletişim: Media and Communication

Halkla İlişkiler: Public Relations

Radyo-Tv-Sinema: Radio-TV-Cinema

Yeni Medya: New Media

Görsel Tasarım: Visual Design

Halkla İlişkiler ve Reklamcılık: Public Relations and Advertising

Halkla İlişkiler-Tanıtım: Public Relations-Publicity

Gazetecilik: Journalism 
While it was revealed that twenty-four different department names were used under the roof of communication faculties, the name "Radio, television and cinema" was at the first place with thirty-seven times in the names of the faculties of communication examined, "journalism" was used in thirty-two departments. "Public relations and advertising" and "public relations and publicity" departments, which are quite similar in terms of the teaching staff profile and curriculum, both came third and fourth. The "other" in the graph was revealed as the sum of the names of the departments which were used only once at faculties.

The fact that the department name of radio-television and cinema is the most frequently used name at the faculties of communication is not a coincidence. Indeed, Communication Faculties with radio-television-cinema departments can be allocated at local frequencies and channels free-of-charge according to Article 24 of the Law No. 3984 on the Establishment and Broadcasts of Radio and Television. However, this right was not given to the Faculties of Fine Arts that include Cinema TV, Cinema and Television (Varol and Alemdar, 2007:8). It is observed that faculties focus on internet broadcasting due to the problems encountered in finding a frequency in the recent period, changes in viewer-listener habits, and increased costs and problems in finding the qualified staff. The department of visual communication design that has started to be opened at foundation universities at the faculties of communication frequently especially in recent years ranked at the last place since it is under the faculty of fine arts in certain state universities.

The curricula of the relevant departments were also examined within the scope of the study, so as not to go beyond the aim and scope of the study, and it was determined that it is aimed to raise graduates for the sector (practical training) or the Academy (theoretical training) rather than the "communication as a skill" approach in many departments that provide communication education. This approach definitely has many justifiable aspects within itself, but upon examining the present student and graduate profiles of the faculty of communication, it is observed that it lacks the features that basic communication should have, such as "effective communication, body language, the use of the place, say, getting rid of the difficulties in communication", and it will be suitable to add courses that will introduce such skills to the curriculum. For, nowadays, graduates of communication can rarely find a job in the communication sector, graduates of the faculty of communication can participate in the working life mainly in other branches, or remain unemployed for a long time.

When we make an assessment on the subject considering that some of the graduates from communication faculties try to become civil servants, the KPSS (Public Selection Examination Test) quality code for civil servant recruitment in the fields of radio, television and cinema in the KPSS, which is the test performed for civil servant recruitment in Turkey, is 4285, and it includes the departments of radio, cinema and television; radio-TV and cinema, radio-TV, cinema, radio-TV and cinema, radio-TVcinema and visual arts, radio and television or radio-TV, cinema, cinema and television, cinema-tv, cinema-TV, photography, cinema TV-photography. In other words, we can see that different department names at universities for radio, television and cinema departments do not constitute any problem regarding the KPSS. When other departments at communication faculties are also examined, it is found out that different department names do not constitute a problem in the field of the KPSS.

\section{Suggestions:}

\section{1) Accreditation}

The main objective of the study is to make an observation on the level of department name differences in the education of communication given in Turkey at the university level, or whether the use of different names is for the sake of students. The names of 
the departments at communication faculties most of which have not admitted any student will continue to change in line with the needs of the sector, changes encountered/being encountered in mass communication tools and the development/changes that will occur in student profiles. At this point, my personal pointof-view is that the names of the departments maintain their development by getting closer to one another further, completing the accreditation of certain basic communication faculty departments to be determined, and making a job definition or standardization for the individuals who studied communication. For example; if a student who studied "journalism" graduates from all our universities with the same formation, this department name confusion will be eliminated. In this respect, the subject has frequently been brought to the agenda in the ILDEK (Faculty of Communication Deans Executive Committee), which is among the most important representatives of Turkey in the academic field since 2010, and the studies have been brought to the last stage. The fulfilment of this study has a huge importance at the point of finding a job at the European Union level by university students, and not finding a job in Turkey only.

\section{2) The Transfer of the Departments of Communication at the Faculties of} Communication

As it is partially mentioned in the findings part of the study, it was observed that certain departments that are supposed to be under the roof of communication in certain universities continue education at the faculties of fine arts and even faculties of business management. The main duty to be performed here is the completion of the transfer of the relevant departments to the faculties of communication, and updating the curricula in accordance with the education of communication. The lack of the faculties of communication at the relevant universities is a subject that can be solved by establishing faculties of communication at the relevant universities in the long term.

\section{3) Decrease in Student Admission}

With the recent increase in the number of faculties of communication in Turkey, the number of the faculty of communication students and the number of communication faculty graduates naturally rapidly increase. However, as the number of graduates is much above the sector's needs, many graduates fail to find a job after their graduation for a long time, and most of those who find a job, find it in a different sector. On the other hand, there is huge intensity in master's degree programs that people tend towards both for their personal interests and qualifications, and the failure to find a job in the sector, and almost all faculties that give communication education open at least one master's degree program in the field of social sciences. The same problem occurs in students who have their master's degree, and even a graduate profile that is not even considered by the employer for having a master's degree emerges. At this point, one of the studies that are suggested to be performed is the decrease in the number of students in student admission at master's level. If universities that admit 100 students each year reduce their quotas half-and-half, both the excessive number of graduates of the sector will be eliminated, therefore, preventing the arbitrary selections of employers, and more qualified training will be provided to students at the faculties of communication.

\section{4) Dissemination of Distance Education}

The distance education format, the first example of which in Turkey we saw within Anadolu University Faculty of Distance Education, opened in other universities and faculties subsequently, but its rate of dissemination is quite low. As for the field of communication, there is no faculty that gives distance education. In this sense, it is necessary to pave the way for distance education in the field of communication by choosing certain faculties of communication that are sufficient in being qualified in infrastructure, and the number of the teaching staff as pilot universities. This will both provide convenience to the teaching staff lecturing hundreds of students in the same lecture halls at universities with a high number of students, and give the students who "are not present" in these lecture halls the opportunity to follow lessons in a more qualitative way. 


\section{References}

Arslan, H. (2015). "Bologna Sürecinde İletişim Fakülteleri: Adnan Menderes Üniversitesi Özelinde Bir Değerlendirme [Faculties of Communication in the Bologna Process: An Assessment within Adnan Menderes University]". Türk\&İslam Dünyası Sosyal Araştırmalar Dergisi Issue:3 p.35-56

Örücü and Şimşek. (2011). "Akademisyenlerin Gözünden Türkiye'de Eğitim Yönetiminin Akademik Durumu: Nitel Bir Analiz [Academic Situation of Education Management in Turkey from the Point-of-View of Academicians: A Qualitative Analysis]". Kuram ve Uygulamada Eğitim Yönetimi Degisi volume: 17, Issue:2 p. 167-197

Tokgöz, O. (2006). "Türkiye'de İletişim Araştırmalarında İletişim Eğitiminin Rolü ve Önemi [Role and Importance of Communication Education in Communication Studies in Turkey]". Küresel iletişim Dergisi Issue:1 p. 1-12

Uzun, R. (2007). "İstihdam sorunu bağlamında Türkiye'de iletişim eğitimi ve öğrenci yerleştirme [Communication education and student placement in Turkey in the context of employment problem]". İletişim kuram ve araştırma dergisi. Issue: $25 \mathrm{p}$. 117-134

Varol A. and Alemdar K. (2007). "İletişim fakültelerine öğrenci yerleştirmede karşılaşılan çelişkiler ve çözüm önerileri [Contradictions encountered in student placement at the faculties of communication and solution suggestions]". İletişim kuram ve araştırma dergisi Issue: 24 p. 1-1

Mustafa Özgür Seçim has a phd. degree from the department of advertising, Ege University in 2013. After working in Izmir University of Economics for 5 years as a research assistant, he's been working in Adnan Menderes University, department of public relations and advertising as an assistant professor. His current reseacrh areas are political communication, social media and advertising theories. 